\title{
Epidemiology of ovarian cancers in Zaria, Northern Nigeria: a 10-year study
}

\author{
This article was published in the following Dove Press journal: \\ International Journal of Women's Health \\ Number of times this article has been viewed
}

\author{
Marliyya Sanusi Zayyan' \\ Saad Aliyu Ahmed ${ }^{2}$ \\ Adekunle O Oguntayo' \\ Abimbola O Kolawole' \\ Tajudeen Ayodeji Olasinde 3 \\ 'Gynaecological Oncology Unit, \\ ${ }^{2}$ Department of Histopathology, \\ ${ }^{3}$ Department of Radiation Oncology, \\ Ahmadu Bello University, Zaria, \\ Nigeria
}

Background: Globally, the absence of a premalignant stage of ovarian cancer and a reliable screening tool make early diagnosis difficult. Locally, poverty, ignorance, and lack of organized cancer services make prognosis poor. We describe the epidemiological features of ovarian cancer seen at Ahmadu Bello University Teaching Hospital Zaria, Northern Nigeria, a tertiary referral center, over a 10 -year period in this challenging setting.

Methods: All cases of histologically diagnosed ovarian cancer between January 1, 2004 and December 31, 2013 were included in the study. Case notes were retrieved to collect clinical data including age, parity, clinical stage of disease at presentation, and known associated factors. Results were analyzed using Epi info ${ }^{\mathrm{TM}}$.

Results: A total of 78 patients were included in the study. About 4-13 cases were seen every year with a tendency to increasing incidence. The patients were aged $8-80$ years with mean of 37 years. Sixty-two (79.5\%) patients were premenopausal while postmenopausal women accounted for only seven cases or $9.0 \%$. There were 17 cases $(22.3 \%)$ of aggressive cancers in patients aged $\leq 20$ years. A majority of the patients, $65(83.3 \%)$, were parous with only nine (11.5\%) patients being nulliparous. Serous cyst adenocarcinoma accounted for $32(41 \%)$ cases. Granulosa cell tumor was the second commonest with 18 cases $(23.1 \%)$. The mean age of occurrence of serous cyst adenocarcinoma was 31 years and for epithelial ovarian cancers in general it was 33.5 years. Endometrioid adenocarcinoma was rare with only one case in 10 years. Factors like age, parity, and premenopausal status did not appear to be protective to the occurrence of malignant ovarian tumor in this group.

Conclusion: Increasing numbers of patients with ovarian cancer were seen over the 10-year period. Young, premenopausal, parous women made up the majority of cases. Serous cystadenocarcinoma was the most common histological variant.

Keywords: ovarian cancer, premenopausal parous women, serous cystadenocarcinoma

\section{Background}

Ovarian cancer, the second commonest gynecological malignancy among Nigerian women after cervical cancer, ${ }^{1-6}$ is the most challenging in terms of its causation and biology. Lack of knowledge of a premalignant stage, the absence of a reliable screening tool, and inaccessibility of the ovary to screening further complicate the problem. Nigeria shares in the universal observation of late presentation for ovarian cancer as more than $75 \%$ of cases present in advanced stages ${ }^{7,8}$ but the challenges in management including lack of organized cancer care worsen the prognosis..$^{9,10}$

Little is known about the etiology of this disease but commonly cited risk factors include age, family history, infertility, or use of ovulation induction agents while protective factors include increasing parity, oral contraceptive use, and oophorectomy. Lactation, incomplete pregnancies, and surgeries such as hysterectomy and
Correspondence: Marliyya Sanusi Zayyan Gynaecological Oncology Unit, Department of Obstetrics and Gynaecology, Ahmadu Bello University, Zaria, Nigeria

Tel +23470397587 76

Email marliyya.zayyan@gmail.com 
tubal ligation may confer a weak protective effect against ovarian cancer. ${ }^{11-13}$

Clinical experience in Africa contradicts the importance of these risk factors and suggests others that require further research. ${ }^{14-18}$ The general belief is that ovarian cancer is more common in developed countries especially in North and West Europe and the USA than in Asia and Africa. ${ }^{12,19}$ African-Americans are reported to have a lower incidence of ovarian cancer but have a poorer prognosis compared to their white counterparts. ${ }^{19}$ This implies that environmental and lifestyle factors may explain the difference in both incidence and outcome between Africans living in Africa and African-Americans in the USA. With a population of 188 million, ${ }^{20}$ Nigeria is the largest black nation in the world making findings in Nigerian women to be highly representative of black women. There is no national study on ovarian cancer from Nigeria but reports on this subject reveal interesting findings that require further exploration. ${ }^{1-6,9,10}$

A 10-year case series in a large tertiary center was undertaken to highlight the pattern of ovarian cancer and relevance of known risk factors in association with the disease.

\section{Aims and objectives}

We studied the epidemiology of ovarian cancer at Ahmadu Bello University Teaching Hospital (ABUTH), a large tertiary center, over a 10-year period, to highlight the frequency and pattern of the disease and its association with known risk factors, and identify the group of women most affected, as well as the common histological types.

\section{Methods}

This was a retrospective clinico-pathological observational study of patients with primary ovarian cancer at ABUTH, a center built by merging its three different satellites 12 years ago. It is a regional referral center of excellence for oncology and one of seven in the country with facilities for radiotherapy. The center provides services for both diagnosis and treatment of gynecological malignancies including ovarian cancer. Its catchment population is mainly from Northern Nigeria but also from neighboring Niger and Chad republics.

Ethical approval was granted by the ABUTH Shika Research Ethics Committee with recommendation to anonymize the clinical records to resolve the issue of consent, as many of the subjects were deceased.

A manual search of the histopathology register for all patients with a histological diagnosis of ovarian cancer between January 1, 2004, and December 31, 2013, was undertaken and the records were retrieved. The clinical case notes were then retrieved from the Medical Records Department and the data were collected using a proforma. Furthermore, manual cross searches were undertaken from radiology (of computed tomography [CT] scans) and immunology (of CA-125) records to corroborate the primary search information and obtain any additional cases. Inclusion criteria used were all cases with histological or cytological diagnosis of ovarian cancer while benign disease, equivocal cases, and metastatic cancers to the ovary were excluded. Incomplete data sets and missing clinical records in a system that is yet to be fully computerized limit this study. Data were analyzed using Epi info version 7.

\section{Results}

A total of 85 patients fulfilled the criteria for inclusion in the study but two folders could not be traced, and five patients had incomplete records and were excluded. Therefore, 78 patients were included, and they had histological diagnosis of primary ovarian malignancy over the study period (Table 1; Figure1). Patients were aged between 8 and 80 years. The mean age of the patients was $35.5 \pm 1.5$ years. Patients aged $41-50$ years were most affected accounting for 20 (25.6\%) of the cases. The age groups $11-20$ and $51-60$ years contribute 13 cases (16.7\%) each. Table 2; Figure 2; [CI 30-44\%]).

A majority of the patients, $65(83.3 \%)$ were parous women. Some $4(5.1 \%)$ patients were premenarcheal, and only $9(11.5 \%)$ patients were nulliparous. The mean parity of the group was 4.5 children.

All histological subtypes of ovarian cancer were seen but serous cyst adenocarcinoma (SCA) accounted for 32 cases $(41.2 \%)$ while granulosa cell tumor (GCT) occurred in 20 patients $(25.6 \%$, [Table 3; Figure 3$]$ ).

The mean age of occurrence of SCA was $33.5 \pm 0.5$ years. Mucinous cyst adenocarcinoma (MCA) cancers were seen in older women so the mean age of occurrence of epithelial

Table I Cases by year of ovarian cancer seen at ABUTH, Zaria, Nigeria

\begin{tabular}{ll}
\hline Year & Cases \\
\hline 2004 & 4 \\
2005 & 6 \\
2006 & 6 \\
2007 & 7 \\
2008 & 10 \\
2009 & 9 \\
2010 & 4 \\
2011 & 7 \\
2012 & 13 \\
2013 & 12 \\
Total & 78 \\
\hline
\end{tabular}

Abbreviation: ABUTH, Ahmadu Bello University Teaching Hospital. 


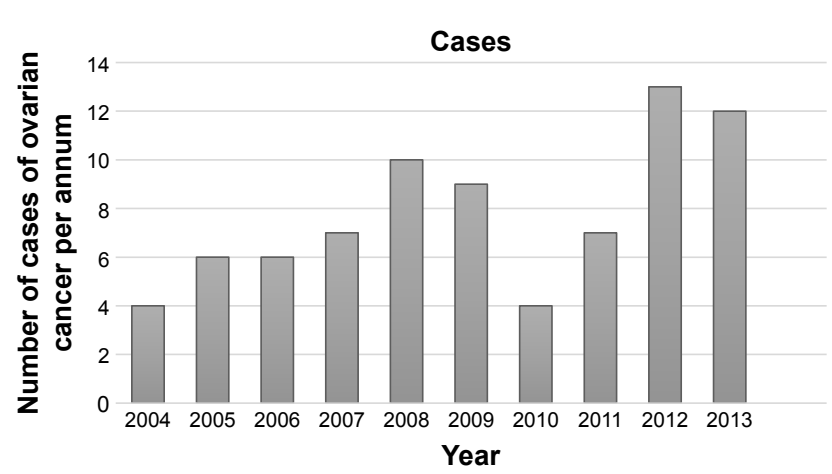

Figure I Bar chart trend in frequency of ovarian cancer seen at ABUTH. Abbreviation: ABUTH, Ahmadu Bello University Teaching Hospital.

cancers was $35.5 \pm 1.5$ years while patients with GCT were slightly older with average age of $36 \pm 1.5$ years (Table 4 ).

There were 62 cases $(79.5 \%)$ of ovarian cancer in premenopausal women and only 5 cases $(6.4 \%)$ were seen in patients aged $>60$ years (Table 5 [CI 27\%-52\%]).

Sixty-three patients $(80.8 \%)$ presented in stages 3 and 4 but $45(57.6 \%)$ were operable at presentation.

\section{Discussion}

Ovarian cancer is an important public health problem especially, as forms of ovarian cancer are so varied, each with different biology and prognosis. It remains the most fatal of gynecologic malignancies. ${ }^{12,13}$ Racial and geographic disparities in incidence have stimulated research into epidemiological factors associated with the disease, and studies indicate that the traditional risk factors often cited for ovarian cancers may not be universally applicable. ${ }^{11-14}$ The frequency of ovarian cancer at our institution appears to be rising. The apparent drop noticed between 2009 and 2011 may be due to multiple industrial actions by healthcare workers during this period necessitating closure of the service and diversion of cases. ${ }^{21}$

This rising trend with time has been confirmed by reports from other centers in the country. Mohammed et al reported 43 cases only in the previous decade from the same centre. ${ }^{22}$ Buhari et al from Ilorin report only 80 cases over 20 years. ${ }^{16}$

Table 2 Frequency of ovarian cancer by age range

\begin{tabular}{lll}
\hline Age range (years) & Cases & Percentage \\
\hline$I-10$ & 4 & 5.1 \\
$I I-20$ & 13 & 16.7 \\
$2 I-30$ & 12 & 15.4 \\
$3 I-40$ & 11 & 14.1 \\
$4 I-50$ & 20 & 25.6 \\
$5 I-60$ & 13 & 16.7 \\
$6 I-70$ & 4 & 5.1 \\
$7 I-80$ & 1 & 1.3 \\
Total & 78 & 100 \\
\hline
\end{tabular}

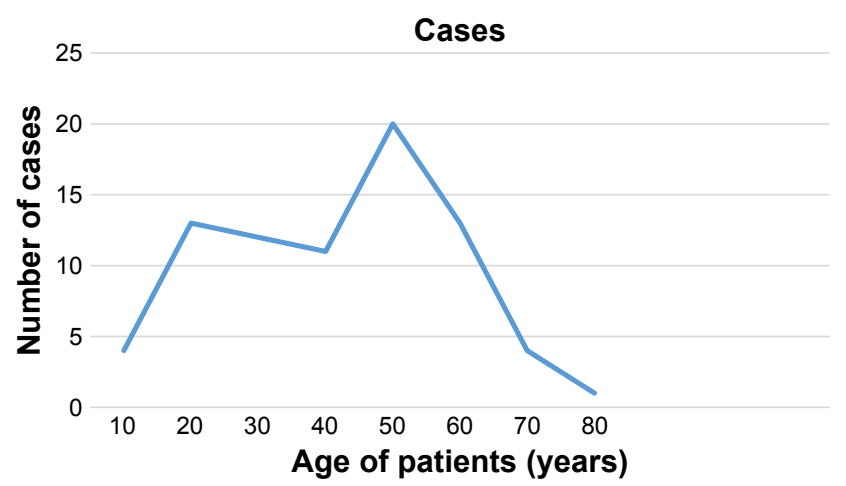

Figure 2 Frequency polygon of cases by age of ovarian cancer seen at ABUTH. Abbreviation: ABUTH, Ahmadu Bello University Teaching Hospital.

Similar reports from Ibadan ${ }^{15,23}$ and other parts of Nigeria also suggest a rising frequency. 5,9,24 This may however also reflect an increasing awareness of the disease and utilization of services, as suggested by some. ${ }^{24}$

Ovarian cancer is known to be predominantly a disease of older women with incidence rising steeply after the menopause. Over $80 \%$ of new diagnoses are normally in women over the age of 50 years. $^{25,26}$ The peak incidence of occurrence is normally $80-84$ years. ${ }^{11-13}$ This study, however, shows a younger age occurrence of the disease as women aged $\leq 50$ years accounted for $76 \%$ of the cases, and $>50 \%$ of cases occurred in women aged $\leq 40$ years. Mohammed et $\mathrm{al}^{22}$ and Onyiorah et $\mathrm{a}^{27}$ also reported a peak incidence at 30-39 years while Kyari et $\mathrm{al}^{6}$ from Maiduguri reported ovarian cancers to be the commonest tumors in a teenage group. Briggs and Katchy found ovarian cancers to be the most common genital malignancies before the age of 40 years. ${ }^{28}$ Works from other African countries concur with this finding; Akpakpo et al and Nkyekyer from Ghana report 46.5 years as the mean age of occurrence. ${ }^{18,29}$ This is not in consonance with the data from the US Surveillance, epidemiology and end

Table 3 Ovarian cancer by histological type

\begin{tabular}{lll}
\hline Histological type & Number of cases & Percentage \\
\hline Serous cyst adenocarcinoma & 32 & 41 \\
Mucinous cyst AC & 8 & 10.3 \\
Endometroid AC & $\mathrm{I}$ & 1.3 \\
Brenners tumor & $\mathrm{I}$ & $\mathrm{I} .3$ \\
Granulosa cell tumor & 20 & 25.6 \\
Dysgerminoma & 2 & 2.6 \\
Endodermal sinus tumor & 2 & 2.6 \\
Immature teratoma & 5 & 6.4 \\
Malignant teratoma & 2 & 2.6 \\
Embryonal carcinoma & $\mathrm{I}$ & 2.6 \\
Choriocarcinoma & $\mathrm{I}$ & 2.6 \\
Others & 3 & 3.8 \\
Total & 78 & 100 \\
\hline
\end{tabular}

Abbreviation: $A C$, adenocarcinoma. 


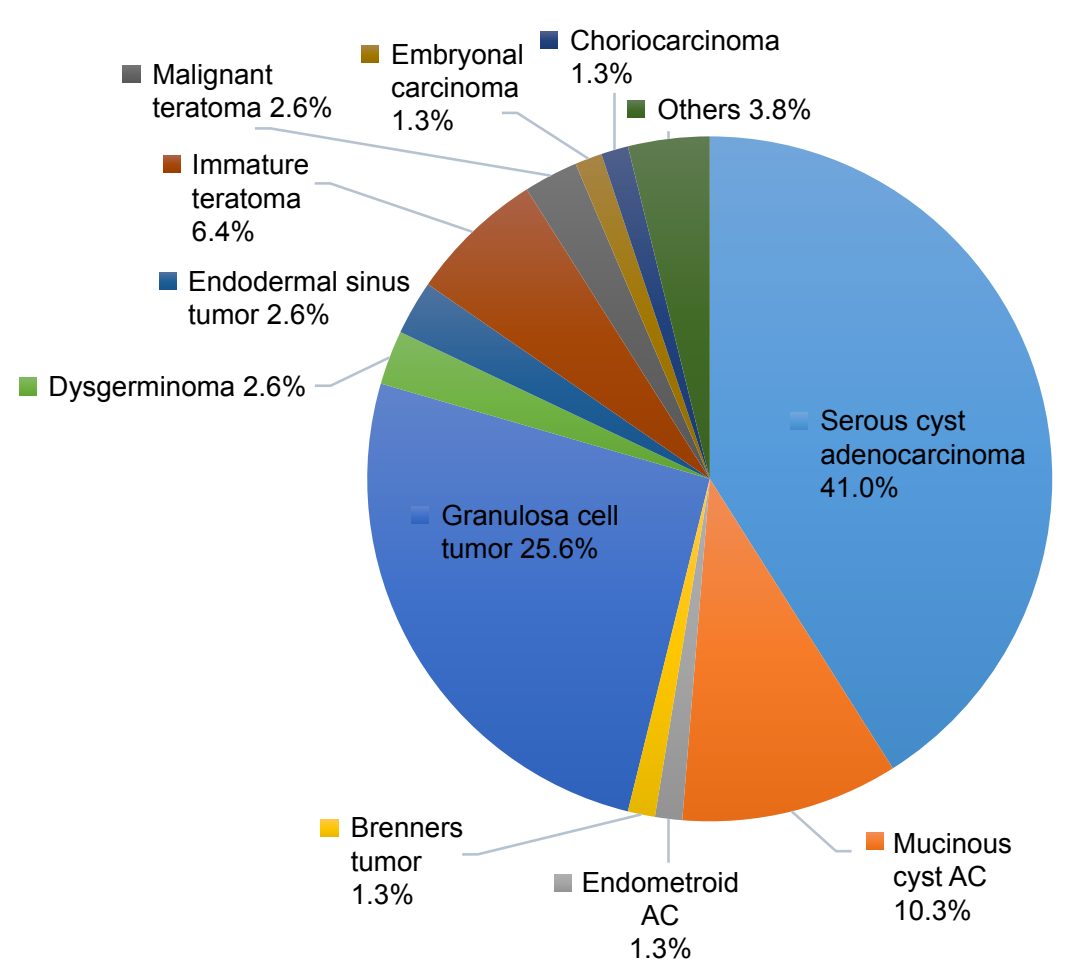

Figure 3 Ovarian cancer by histological subtypes.

Abbreviation: AC, adenocarcinoma.

results (SEER) database that clearly demonstrate the strong relationship between age and ovarian cancer risk. ${ }^{30}$ According to SEER, the incidence is low in women under the age of 40 years, but rises steeply after the fifth decade to reach a peak in the 80- to 84-year-old age group (incidence of 61.8 per 100,000 women). The median age at diagnosis in SEER is 63 years in contrast to 36 years in this report. ${ }^{30}$ These findings of lower age of occurrence of ovarian cancer in this and other studies in Nigeria and parts of Africa may be important in the epidemiology of the disease. But the age-specific incidence rates will be required to confirm these findings.

Increasing parity has also been an established protective factor for ovarian cancer. ${ }^{12,26,31}$ Studies have shown a reduction in risk even with incomplete pregnancies. ${ }^{13,26}$

Table 4 Epithelial ovarian cancer by type and age

\begin{tabular}{llllll}
\hline $\begin{array}{l}\text { Age } \\
\text { (years) }\end{array}$ & SCAC & MCAC & EC & BT & TOTAL \\
\hline$I-10$ & 0 & 0 & 0 & 0 & 0 \\
$I I-20$ & 3 & 0 & 0 & 0 & 3 \\
$2 I-30$ & 3 & 2 & 0 & 0 & 5 \\
$3 I-40$ & 8 & 1 & 0 & 0 & 9 \\
$4 I-50$ & $I 3$ & 2 & 1 & 1 & 17 \\
$5 I-60$ & 4 & 3 & 0 & 0 & 7 \\
$6 I-70$ & $I$ & 0 & 0 & 0 & 1 \\
$7 I-80$ & 0 & 0 & 0 & 0 & 0 \\
Total & 32 & 8 & 1 & 1 & 42 \\
\hline
\end{tabular}

Abbreviations: SCAC, serous cyst adenocarcinoma; MCAC, mucinous cyst adenocarcinoma; EC, endometroid adenocarcinoma; BT, Brenners tumor.
In this study, however, $83 \%$ of the patients were parous with a mean parity of 4.5 , which although lower than the national rate 6 , still contradicts the observed protective effect of parity. This finding concurs with the majority of reports from Nigeria ${ }^{4-6,9,10}$ and with the series from Lahore by Rashid et al. ${ }^{32}$ This study did not specifically look at other gestation-related factors such as lactation, which is a cultural norm in Africa. This may be worth assessing in the African population as evidence suggests that it may have a protective effect in the Chinese. ${ }^{33}$

Although lower, our finding that epithelial ovarian cancer (EOC) is the commonest form of ovarian cancer is in line with figures from Ibadan (76.2\%), ${ }^{15}$ Enugu (68\%), ${ }^{5}$ Benin $(73.8 \%),{ }^{24}$ and Port Harcourt $(91.2 \%)^{10}$ in the southern parts of Nigeria. In our study, however, it accounts for only $52.6 \%$ of the total with SCA, accounting for the majority (32/41 or $78 \%$ ) of the EOC (Table 3).

Young premenopausal women accounted for $79.5 \%$ of cases with EOC with only $<10 \%$ in postmenopausal women, and $9.3 \%$ of EOC occurred in women aged $\leq 20$ years. This is in sharp contrast with findings in other parts of the world where EOC is a disease of post-menopausal women averaging 70 years. ${ }^{13}$

Sex cord stromal tumors, mainly granulosa cell tumors, are the second largest subtype contributing $25 \%$ of the cases, representing a slight increase over earlier reports from same center when they formed $20.9 \%$. Iyorke et al reported $16 \%$ 
Table 5 Ovarian cancer in premenopausal women

\begin{tabular}{|c|c|c|c|c|c|}
\hline $\begin{array}{l}\text { Age group } \\
\text { (years) }\end{array}$ & $\begin{array}{l}\text { Epithelial ovarian } \\
\text { cancers, } \mathbf{N}=\mathbf{2 9}\end{array}$ & $\begin{array}{l}\text { Sex cord stromal } \\
\text { tumors, } N=19\end{array}$ & $\begin{array}{l}\text { Germ cell } \\
\text { tumors, } N=12\end{array}$ & $\begin{array}{l}\text { Others, } \\
\mathbf{N}=\mathbf{2}\end{array}$ & Total \\
\hline $11-20$ & $3(10.3)$ & $4(2 I . I)$ & $5(41.7)$ & I (50.0) & $13(21.0)$ \\
\hline $21-30$ & $5(17.2)$ & $6(31.6)$ & $4(33.3)$ & 0 & $15(24.2)$ \\
\hline $31-40$ & $4(13.8)$ & 4 (2I.I) & $3(25.0)$ & & II (I7.7) \\
\hline $4 I-50$ & $10(34.5)$ & $I(5 . I)$ & 0 & I (50.0) & $12(19.4)$ \\
\hline $51+$ & 7 (24.2) & $4(2 I . I)$ & 0 & & II (I7.7) \\
\hline Total & $29(100.0)$ & $19(100.0)$ & $12(100.0)$ & $2(100.0)$ & $62(100.0)$ \\
\hline
\end{tabular}

Note: Data is presented as $\mathrm{n}(\%)$.

in his review of 10 years from Eastern Nigeria, ${ }^{9}$ which is similar to the 3-year review from Kano. ${ }^{34}$ Umanah had 20\% from the Niger Delta. ${ }^{4}$ Most cases $(71.4 \%)$ also occurred in young premenopausal women. The relative high prevalence of granulosa cell tumor may account for the observed lower incidence of EOCs.

In light of our findings of young parous women with EOC, a recent study from Ibadan is of interest. ${ }^{35}$ It reports a high prevalence of BRCA 1 and 2 mutations and number of other mutations yet to be reported in the literature. ${ }^{35} \mathrm{BRCA}$ mutation is associated with not only five times the normal risk for breast cancer but also 10-30 times that of ovarian cancer. ${ }^{36}$ However, having high-risk mutation does not predict that the woman will develop any type of cancer, or imply that the cancer she developed was actually due to the mutation, rather than some other factors, and genetic predisposition is generally responsible for only $5 \%-10 \%$ of cases. ${ }^{37}$

The findings of this study are, however, limited by the very few numbers, and being a single-hospital-based review as such inadequate to draw conclusions, but do shed some light to possible variations in the epidemiology of ovarian cancer.

\section{Conclusion}

Increasing frequency of ovarian cancer is reported in the 10-year period of study, affecting mostly young parous premenopausal women. Main histological types seen in the majority of the women were SCA and GCT. The findings in this study are not in consonance with common reports on the subject.

\section{Acknowledgment}

The abstract of this paper has been presented at the 15 th Biennial Meeting of the International Gynaecologic Cancer Society Melbourne, Australia, November 8-11, 2014, and was published in the International Journal of Gynaecologic Cancer, Volume 24, Supplement 4, November 2014.

\section{Disclosure}

The authors report no conflicts of interest in this work.

\section{References}

1. Oguntayo OA, Zayyan M, Akpa M, Kolawole OA. The burden of Gynaecological Cancer Management in northern Nigeria. Open J Obstet Gynaecol. 2013;3:634-638.

2. Sanni WO, Ocheke AN, Oyebode T, et al. Pattern of gynaecological malignancies in Jos. Trop J Obstet Gynaecol. 2013;30(1):97-101.

3. Airede LR, Malami SA. A five-year review of female genital tract malignancies in Sokoto, northwestern Nigeria. Mary Slessor J Med. 2005;5: $51-56$.

4. Umanah IN, Ugiagbe EE, Olu-Eddo AN. Female genital malignancies in a Niger Delta Region of Nigeria. Ibom Med J. 2013;6(1):23-28.

5. Okeke TC, Onah N, Ikeakoh LC, Ezenyeaku CCT. The frequency and pattern of female genital malignancy at the University of Nigeria Teaching Hospital, Enugu Nigeria. Ann Med Health Sci Res. 2013;3(3): 345-348.

6. Kyari O, Nggada H, Mairiga A. Malignant tumours of the female genital tract in North eastern Nigeria. East Afr J. 2004;81:142-146.

7. Berrino F, De Angelis R, Sant M, et al. EUROCARE Working group Survival for eight major cancers and all cancers combined for European adults diagnosed in 1995-1999: results of the EUROCARE-4 study. Lancet Oncol. 2007;8(9):773-783.

8. Ovarian cancer statistics Oxford: Cancer Research UK; 2013. Available from: http://www.cancerresearchuk.org/cancer-info/cancerstats/types/ ovary/. Accessed June 22, 2017.

9. Iyorke CA, Ugwu GO, Ezugwu EC, Ezugwu FO, Lawani LO, Onyebuchi AK. Challenges associated with gynaecological cancers in a tertiary hospital in South East Nigeria. Int J Womens Health. 2014;6: 123-130.

10. Bassey G, Nyengidiki TK, Inimgba NM, Otoide A. Clinical and histopathological patterns of ovarian malignancy in the University of Port Harcourt teaching hospital. Port Harcourt Med J. 2016;10(1): 14-20.

11. Fathalla MF. Factors in the causation and incidence of ovarian cancer. Obstet Gynecol Survey. 1972;27(11):751-768.

12. Permuth-Wey J, Besharat A, Sellers TA. Editor, Samir A Farghaly. Epidemiology of ovarian cancer: an update. In: Advances in Diagnosis and Management of Ovarian Cancer. New York: Springer. 2014:1-21.

13. Doukefas K, Olaitan A. Clinical epidemiology of epithelial ovarian cancer in the UK. Int $J$ Womens Health. 2014;6:537-545.

14. Saeed MEM, Cao J, Fadul B, et al. A five-year survey of cancer prevalence in Sudan. Anticancer Res. 2016;36(1):279-286.

15. Odukogbe AA, Adebamowo CA, Ola B, et al. Ovarian cancer in Ibadan: characteristics and management. J Obstet Gynaecol. 2004;24(3): 294-297.

16. Buhari MO, Ojo BA, Ijaiya MA, Aboyeji PA. Ovarian cancer in Ilorin, Nigeria: a review of over 80 cases. Nig $Q J$ Hosp Med. 2005;15(3): 127-130.

17. Bassey EA, Ekpo MD, Abassiatai A. Female genital tract malignancies in Uyo, South-South Nigeria. Niger Postgrad Med J. 2007;14(2): 134-136.

18. Nkyekyer K. Pattern of gynecological cancers in Ghana. East Afr Med J. 2000;77(10):534-538.

19. Hunn J, Rodriguez GC. Ovarian cancer: etiology, risk factors and epidemiology. Obstet Gynaecol. 2012;55(1):3-23 
20. Human Development Report Statistical Annex (PDF). United Nations Development Programme; 2015: 18. http://hdr.undp.org/sites/default/ files/hdr_2015_statistical_annex.pdf. Accessed September 26, 2017.

21. Vanguard. [wepage on the Internet]. Komolafe F, Ogundipe, AhiumaYoung AV, \& Adesulu D. Health workers suspend strike. Vanguard 13th July 2009 available at https://www.vanguardngr.com/2009/07/ health-workers-suspend-strike/. Accessed September 26, 2017.

22. Mohammed A, Ahmed SA, Oluwole OP, Avidime S. Malignant tumours of the female genital tract in Zaria, Nigeria: analysis of 513 cases. Ann Afr Med. 2006;5:93-96.

23. Babarinsa IA, Akang EEU, Ademole IF. Pattern of gynaecological malignancies at the Ibadan Cancer Registry (1976-1995). Nig Q J Hosp Med. 1998;8:103-112.

24. Gharoro EP, Eirewele O. Cancer of the ovary at the University of Benin Teaching Hospital: a 10-year review, 1992-2001. Afr J Med Med Sci. 2006;35(2):143-147.

25. De Angelis R, Sant M, Coleman MP, et al. EUROCARE-5 working group cancer survival in Europe 1999-2007 by country and age: results of EUROCARE-5-a population-based study. Lancet Oncol. 2014;15(1):23-34.

26. Edmondson RJ, Monaghan JM. The epidemiology of ovarian cancer. Int J Gynecol Cancer. 2001;11(6):423-429.

27. Onyiaorah IV, Anunobi CC, Banjo AA, Fatima AA, Nwankwo KC. Histopathological patterns of ovarian tumours seen in Lagos University Teaching Hospital: a ten-year retrospective study. Nig Q J Hosp Med. 2011;21(2):114-118.

28. Briggs ND, Katchy KC. Pattern of primary gynaecology malignancies as seen in a tertiary hospital situated in River State of Nigeria. Int $J$ Gynaecol Obset. 1990;31:157-161.
29. Akakpo PK, Derkyi-Kwarteng L, Gyasi RK, Quayson SE, Anim JT. Ovarian cancer in Ghana, a 10 year histopathological review of cases at Korle Bu Teaching Hospital. Afr J Reprod Health. 2015;19(4): $102-106$.

30. Whittemore A, Harris R, Itnyre J. Characteristics relating to ovarian cancer risk: collaborative analysis of 12 US case-control studies IV. The pathogenesis of epithelial ovarian cancer. Collaborative Ovarian Cancer Group. Am J Epidemiol. 1992;136(10):1212-1220.

31. Risch HA, Marrett LD, Howe GR. Parity, contraception, infertility, and the risk of epithelial ovarian cancer. Am J Epidemiol. 1994;140(7): 585-597.

32. Rashid S, Sarwar G, Ali A. A clinico-pathological study of ovarian cancer. Mother Child. 1998;13(4):117-125.

33. Su D, Pasalich M, Lee AH, Binns CW. Ovarian cancer risk is reduced by prolonged lactation: a case-control study in southern China. Am J Clin Nutr. 2013;97(2):354-359.

34. Yakasai IA, Ugwa EA, Otubu J. Gynaecological malignancies in Aminu Kano Teaching Hospital: a three year review. Niger J Clin Pract. 2013; 16(1):63-66.

35. Fackenthal JD, Zhang J, Zhang B, et al. High prevalence of BRCAI and $B R C A 2$ mutations in unselected Nigerian breast cancer patients. Int J Cancer. 2012;131:1114-1123.

36. Morris JL, Ora OK. Positive results: making the best decisions when you're at high risk for breast or ovarian cance. pp. 337-340. 2010, Prometheus Books, Amherst, NY

37. Banks KC, Moline JJ, Marvin ML, Newlin AC, Vogel KJ. 10 rare tumors that warrant a genetics referral. Fam Cancer. 2013;12(1):1-18.
International Journal of Women's Health

\section{Publish your work in this journal}

The International Journal of Women's Health is an international, peerreviewed open-access journal publishing original research, reports, editorials, reviews and commentaries on all aspects of women's healthcare including gynecology, obstetrics, and breast cancer. The manuscript management system is completely online and includes

\section{Dovepress}

a very quick and fair peer-review system, which is all easy to use. Visit http://www.dovepress.com/testimonials.php to read real quotes from published authors. 